\title{
DELAYED RENAL GRAFT FUNCTION IN THE EARLY POST-TRANSPLANT PERIOD AND ITS IMPACT ON THE LATE POST-TRANSPLANT RESULTS
}

\author{
Jānis Jušinskis*, **, Diāna Amerika*, **, and Aleksandrs Maḷcevs*, ** \\ * Rīga Stradiṇ̌ University, Transplant Laboratory, Dzirciema iela 16, Rīga, LV-1007, LATVIA; \\ Jushinskis@ transplantation.Iv \\ ** Pauls Stradiṇš University Hospital, Latvian Transplantation Centre, Pilsoṇu iela 13, Rĩga, LV-1002, LATVIA
}

Communicated by Rafails Rozentāls

\begin{abstract}
Delayed renal graft function (DGF) is a frequent complication with negative impact on the course of early post-transplantation period. The data concerning the impact on the late results are contradictory. This study describes results of 5-year follow-up of 248 recipients after deceased donor renal transplantation. All patients were divided into two groups: with delayed graft function (DGF, $n=53$ ) and immediate graft function, considered as the control group (IGF, $n=195$ ). We evaluated factors that were associated with development of DGF and its impact on the survival of graft and recipient, and frequency of acute rejections and chronic dysfunctions. The rate of observed DGF was $21.4 \%$. Its development was associated with the following factors: age of recipient and their weight, age of donor and their body mass index, high frequency of asystole/hypotension in donors prior to organ explantation ( $\mathrm{P}<0.05$ for all), and longer time of cold ischemia $(\mathrm{P}=0.058)$. The DGF group had higher rate of acute rejections ( $\mathrm{P}<0.001)$, and also lower 1.5 and 5-year graft survival and 1.5-year patient survival $(\mathrm{P}<0.05$ for all). The conclusion is that DGF has negative impact on the survival of renal grafts and patients, especially during the first 1.5 years after transplantation.
\end{abstract}

Key words: kidney transplantation, delayed graft function, patients survival, graft survival.

\section{INTRODUCTION}

Delayed graft function (DGF) is a frequent (10-50\%) complication of the early post-transplantation period (Brier et al., 2003; Sánchez-Fructuoso et al., 2004; Azevedo et al., 2005; Johnston et al., 2006). Ischemia-reperfusion injury and the related graft tubulopathy cause incomplete or even missing function of transplanted kidney, i.e. acute renal failure, which restores continuously during several days or weeks after the transplantation. In cases of missing function it is difficult to diagnose any pathologic changes arising in the graft during this period, for example, an acute rejection. The delayed diagnostics and lack of data regarding treatment of any eventual pathology may cause complications and loss of grafts both in the early and in the late post-operative period (Hernández et al., 2006; Johnston et al., 2006; Quiroga et al., 2006; Sánchez-Fructuoso et al., 2004).

The aim of this study was to identify factors associated with the development of DGF and to define the impact of DGF on post-transplant results and on graft and patient survival in the early and late post-transplantation period.

\section{MATERIALS AND METHODS}

The study included all consecutive kidney transplantations from deceased donors performed in the Latvian Transplantation Centre during the period from 1 January 2004 to 30 November 2007. Exclusion criteria were: recipient death or graft loss during the first week after transplantation due to vascular, immunological or surgical complications (thrombosis, heavy acute rejection, surgical infection). According to these criteria, 248 kidney transplantation cases were included in the study (134 males, 114 females; mean age $45.17 \pm 14.53$ years). Renal grafts were recovered from 172 deceased donors (105 males, 67 females; mean age $42.92 \pm$ 13.30 years).

Donor organ procurement utilised in situ preservation by histidine-tryptophan-ketoglutarate (HTK) solution. The cold ischemia time did not exceed 24 hours, and warm ischemia time - 20 minutes. Donor kidney allocation included ABO-identity and cross-match. Immunosuppression included induction by monoclonal (basilixumab or daclizumab) or polyclonal (ATG) antibodies with a 5-day steroid 
pulse, and maintenance by per oral steroids, mycophenolate mofetil and Neoral as guided by the blood level.

All cases were divided into two groups according to renal graft function: delayed graft function (DGF) or immediate (IGF). DGF was defined as a need for at least one dialysis during the first post-transplantation week. The impact of the graft function on survival of recipient and graft was monitored. Recipient serum creatinine (S-Creatinine) dynamical level was used for the assessment of renal graft function. The rate of acute rejection was evaluated according to renal graft biopsy results (Banff 2007 classification). Chronic renal graft dysfunction was diagnosed clinically (increase in level of S-creatinine by $10 \%$ or more for more than three months during the follow-up) or according to renal graft biopsy results (Banff 2007 classification). The main clinical, biochemical and demographical indices are shown in the Table 1. The follow-up period after transplantation was five years.

Statistical analysis of the groups was performed by T-tests, $\chi^{2}$, ANOVA and Kaplan-Meier survival tests (SPSS 13.0, SPSS Inc.).

\section{RESULTS}

Delayed renal graft function was observed in 53 (21.4\%) of 248 recipients.

Comparison of the DGF and IGF groups according to clinical and demographic data (Table 1) showed differences in recipients age $(50.6 \pm 13.7$ vs. $43.7 \pm 14.3$ years, respectively; $P<0.05)$, recipient weight $(76.0 \pm 20.3$ vs. $70.6 \pm$ $16.6 \mathrm{~kg} ; P<0.05)$, donors age $(47.0 \pm 12.6$ vs. $41.8 \pm 13.3$, $P<0.05)$, donor BMI $\left(27.2 \pm 4.6\right.$ vs. $25.3 \pm 3.8 \mathrm{~kg} / \mathrm{m}^{2}$,
$P<0.01)$ and presence of asystole/hypotension in donors prior to organ explantation $(77.4 \%$ vs. $57.9 \%, P<0.01)$. The cold ischemia time of grafts was longer in the DGF group than in the IGF groups $(17.7 \pm 4.3 \mathrm{vs} .16 .1 \pm 4.7 \mathrm{hrs}$, $P=0.058)$, but this difference did not reach statistical significance.

The study groups did not differ in the number of recipient deaths (14 in the DGF group and 40 in the IGF group, $P=$ NS) and graft loss ( 6 in the DGF group and 26 in the IGF group, $P=\mathrm{NS}$ ) (Table 2).

The rate of acute rejections was higher in the DGF group (75.5\% vs. $35.9 \%$ in the IGF group, $P<0.001)$. Analysis of death-censored graft survival (Fig. 1) showed that the maximum difference occurred during the first 1.5 years after transplantation $(76.6 \%$ vs. $94.3 \%$ for IGF; Log Rank [Mantel-Cox] 16.299; $P<0.001)$. The survival later stabilized and the curves become parallel, although 5-year graft survival was significantly worse in the DGF group $(84.9 \%$ vs. 94.9\% for immediate function; Log Rank [Mantel-Cox] 4.456; $P<0,05)$.

A similar trend was observed also in recipient survival (Fig. 2 ), although differences in 5-year survival between the groups were not statistically significant (Log Rank [MantelCox] $1.631 ; P=\mathrm{NS})$.

The rate of chronic graft dysfunction and level of S-creatinine at 5-year post transplantation did not significantly differ between the DGF and IGF groups $(P=\mathrm{NS})$.

\section{DISCUSSION}

Delayed renal graft function is a serious complication in the post-transplant period, as its frequency varies within a wide

Table 1

DEMOGRAPHIC AND CLINICAL DATA OF DGF AND IGF GROUPS

\begin{tabular}{|c|c|c|c|}
\hline & DGF $(n=53)$ & $\operatorname{IGF}(\mathrm{n}=195)$ & $P$ value \\
\hline \multicolumn{4}{|l|}{ Recipients: } \\
\hline Age (yrs) & $50.6 \pm 13.7$ & $43.7 \pm 14.3$ & 0.002 \\
\hline Gender, male/female (n) & $27 / 26$ & $107 / 88$ & NS \\
\hline Weight (kg) & $76.0 \pm 20.3$ & $70.6 \pm 16.6$ & 0.047 \\
\hline Dialysis type (Hemodialysis/peritoneal dialysis, $\mathrm{n}$ ) & $48 / 5$ & $184 / 11$ & NS \\
\hline Diabetes mellitus (n) & $10(18.9 \%)$ & $22(11.3 \%)$ & NS \\
\hline Retransplantations (n) & $3(5.7 \%)$ & $23(11.8 \%)$ & NS \\
\hline Panel reactive antibodies $>10 \%(\mathrm{n})$ & $2(3.8 \%)$ & $5(2.6 \%)$ & NS \\
\hline \multicolumn{4}{|l|}{ Donors: } \\
\hline Age (yrs) & $47.0 \pm 12.6$ & $41.8 \pm 13.3$ & 0.011 \\
\hline Gender, male/female (n) & $35 / 18$ & $133 / 62$ & NS \\
\hline Body mass index (BMI, kg/m²) & $27.2 \pm 4.6$ & $25.3 \pm 3.8$ & 0.003 \\
\hline Brain death, traumatic/nontraumatic (n) & $27 / 26$ & $110 / 85$ & NS \\
\hline Asystole/hypotension (n) & $41(77.4 \%)$ & $113(57.9 \%)$ & 0.007 \\
\hline S-Creatinine $(\mathrm{mmol} / \mathrm{l})$ & $0.11 \pm 0.04$ & $0.11 \pm 0.04$ & NS \\
\hline S-Urea $(\mathrm{mmol} / \mathrm{l})$ & $6.48 \pm 3.23$ & $6.42 \pm 3.13$ & NS \\
\hline \multicolumn{4}{|l|}{ Transplantation: } \\
\hline Cold ischemia time (hrs) & $17.7 \pm 4.3$ & $16.1 \pm 4.7$ & 0.058 \\
\hline Female donor/male recipient (n) & $12(22.6 \%)$ & $37(19.0 \%)$ & NS \\
\hline Graft vascular reconstructions (n) & $27(50.9 \%)$ & $95(48.7 \%)$ & NS \\
\hline Induction immunosuppression (n) & $46(86.8 \%)$ & $176(90.3 \%)$ & NS \\
\hline
\end{tabular}

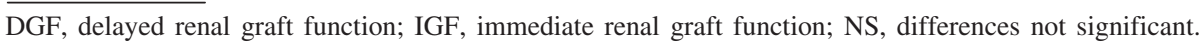


RESULTS AFTER KIDNEY TRANSPLANTATION IN DGF AND IGF GROUPS

\begin{tabular}{|c|c|c|c|}
\hline Results & DGF $(n=53)$ & $\operatorname{IGF}(n=195)$ & $P$ value \\
\hline Patient deaths (n) & $14(26.4 \%)$ & $40(20.5 \%)$ & NS \\
\hline Graft losses (censored for death with functioning graft; $\mathrm{n}$ ) & $6(11.3 \%)$ & $26(13.3 \%)$ & NS \\
\hline Serum creatinine (at $5 \mathrm{yrs}, \mathrm{mmol} / \mathrm{l}$ ) & $0.13+0.03$ & $0,15+0,06$ & NS \\
\hline Chronic graft dysfunctions (n) & $4(7.5 \%)$ & $28(14.4 \%)$ & NS \\
\hline \multicolumn{4}{|l|}{ Patient survival: } \\
\hline 18-months & $84.9 \%$ & $94.9 \%$ & 0.011 \\
\hline 60-months & $77.4 \%$ & $84.1 \%$ & NS \\
\hline \multicolumn{4}{|l|}{ Graft survival: } \\
\hline 18-months & $76.6 \%$ & $94.3 \%$ & $<0.001$ \\
\hline 60-months & $67.9 \%$ & $79.0 \%$ & 0.035 \\
\hline
\end{tabular}

Abbreviations as in Table1
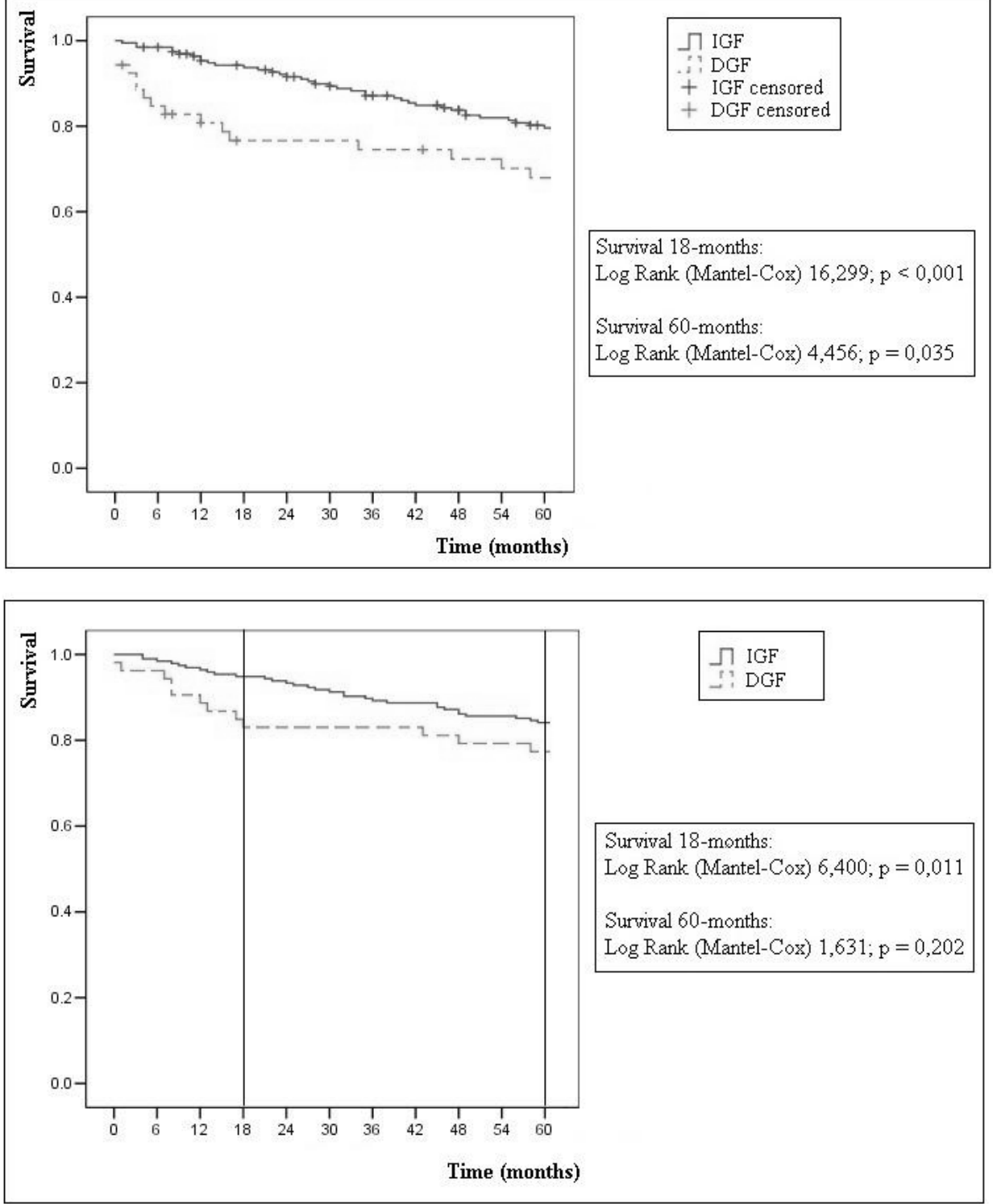

Fig. 1. Five-year graft survival (censored for death with functioning graft). DGF, delayed renal graft function; IGF, immediate renal graft function.
Fig. 2. Five-year patient survival after kidney transplantation. DGF, delayed renal graft function; IGF, immediate renal graft function range and reaches sometimes half of the total number of transplantations (Azevedo et al., 2005). This complication is caused by a number of factors: donor type (deceased or live), warm and cold ischemia time, presence of special means for donor organ perfusion (for example, machine perfusion), induction and maintenance immunosupression regime, etc. (McTaggard et al., 2003; Sanchez-Fructuoso et al., 2004; Boletis et al., 2005; Lodhi et al., 2012).

Considering the negative impact of delayed graft function on the early post-transplant results (continuation of dialysis, increasing number of acute rejections, increased hospitalisa- 
tion time etc.), many transplantation centres endeavour to reduce the cold ischemia time, to use perfusion machines, to apply medicinal and even homeopathic treatment (Grino et al., 1994; Cravedi et al., 2005; Jushinskis et al., 2009; Lodhi et al., 2012). However the permanent shortage of donor organs forces to extend the criteria for organ donation: to use marginal donors, donors after cardiocirculatory death, including donors in the 3rd and 4th category according to Maastricht criteria (Koostra et al., 1995). This, in turn, increases the risk of DGF in the early post-transplant period.

The impact of DGF on the remote results is still disputable. According to the data of some authors, DGF has a negative impact (Johnston et al., 2006; Quiroga et al., 2006), while other studies have not found an effect (Boom et al., 2000; Sola et al, 2004). This difference is due to a number of factors. Up to now there is no united opinion concerning the clear definition of delayed function (Daly et al., 2005). We consider DGF as the necessity of at least one dialysis during the first week after the transplantation, which is the most frequently used definition. However, there are other views concerning the definition of DGF and IGF. DGF has been defined as the need for dialysis during the first 72 hours after transplantation (Hetzel et al., 2002) and there is "slow IGF" definition (Moore et al., 2007). Also the creatinine reduction ratio has been used to define DGF and IGF (Johnston et al., 2006; Moore et al., 2007). It is very difficult to evaluate graft damage degree with objective and scientific methods, in cases when the graft is not functioning. This issue requires a special research, particularly using protocol graft biopsies and the dynamic study of biomarkers in blood, urine and the transplanted kidney (Hartono et al., 2010).

In our study, we found that after five years differences in the graft survival became less prominent, and five-year patient survival was not different between the studied groups. This was probably associated with stabilisation of the course of pathologic processes in grafts that survived this period.

The obtained results can be used to guide management of renal grafts. A "problematic" graft can cause DGF and therefore earlier losses. The transplantation of such kidneys is therefore undesirable in pediatric recipients, who need to extend their life as maximally as possible with the help of the transplantation. Such kidneys should be recommended very cautiously for patients with comorbid diseases, as it may be detrimental to their survival.

In conclusion, delayed graft function has negative impact both on graft and patient survival, particularly during the first two years after the surgery. After this period survival stabilises.

\section{REFERENCES}

Azevedo, L. S., Castro, M. C. R., Monteiro de Carvalho, D. B., d'Avila, D.

O., Contieri, F., Gonēalves, R. T., Manfro, R., Ianhez, L. E. (2005). Inci- dence of delayed graft function in cadaveric kidney transplants in Brazil: A multicenter analysis. Transplant. Proceed., 7, 2746-2747.

Boletis, J., Balitsari, A., Filiopoulos, V., Stamataki, E., Lionaki, S., Zavos, G., Kostakis, A. (2005). Delayed renal graft function: The influence of immunosuppression. Transplant. Proceed., 37 (5), 2054-2059.

Boom, H., Mallat, M. J. K., De Fijter, J. W., Zwinderman, A. H., Paul, L. C. (2000). Delayed graft function influences renal function, but not survival. Kidney Int., 58, 859-866.

Brier, M. E., Ray, P. C., Klein, J. B. (2003). Prediction of delayed renal allograft function using an artificial neural network. Nephrol. Dial. Transplant., 18, 2655.

Cravedi, P., Codreanu, I., Satta, A., Turturro, M., Sghirlanzoni, M.C., Remuzzi, G., Ruggenenti, P. (2005). Cyclosporine prolongs delayed graft function in kidney transplantation: Are rabbit anti-human thymocyte globulins the answer? Nephron. Clin. Practice, 101, c65-c71.

Daly, P. J. A., Power, R. E., Healy, D. A., Hickey, D. P., Fitzpatrick, J. M., Watson, R. W. G. (2005). Delayed graft function: A dilemma in renal transplantation. BJU Int. (British Journal of Urology), 96, 498-501.

Grino, J. M. (1994). BN 52021: A platelet activating factor antagonist for preventing post-transplant renal failure. Ann. Int. Med., 121 (5), 345-347.

Hartono, C., Muthukumar, T., Suthanthiran, M. (2010). Noninvasive diagnosis of acute rejection of renal allografts. Curr. Opin. Organ Transplant., 15 (1), 35-41.

Hernández, D., Rufino, M., Armas, S., González, A., Gutiérrez, P., Barbero, P., Vivancos, S., Rodríguez, C., Rodríguez de Vera, J., Torres, A. (2006). Retrospective analysis of surgical complications following cadaveric kidney transplantation in the modern transplant era. Nephrol. Dial. Transplant., 21, 2908-2915.

Hetzel, G.R., Grunberg, W., Boltres, A., Plum, A., Grabensee, B., Plum, J. (2002). Influence of delayed graft function on glomerular hemodynamics and permselectivity in well-functioning renal allografts. Transplant Proceed., 34, 2203-2204.

Johnston, O., O’Kelly, P., Spencer, S., Donohoe, J., Walshe, J. J., Little, D. M., Hickey, D., Conlon, P. J. (2006). Reduced graft function (with or without dialysis) vs immediate graft function: A comparison of long-term renal allograft survival. Nephrol. Dial. Transplant., 21, 2270-2274.

Jushinskis, J., Trushkov, S., Bicans, J., Suhorukov, V., Shevelev, V., Ziedina, I., Rozental, R. (2009). Risk factors for the development of delayed graft function in deceased donor renal transplants. Transplant. Proceed., 41 (2), 746-748.

Koostra, G., Daemen, J. H. S., Domen, A. P. A. (1995). Categories of non-heart beating donors. Transplant. Proceed., 27, 2893-2894.

Lodhi, S. A., Lamb, K. T., Uddin, I., Meier-Kriesche, H. U. (2012). Pulsatile pump decreases risk of delayed graft function in kidneys donated after cardiac death. Amer. J. Transplant., doi: 10.1111/j.1600-6143.2012.04179.x.

McTaggart, R. A., Gottlieb, D., Brooks, J., Bacchetti, P., Roberts, J. P., Tomlanovich, S., Feng, S. (2003). Sirolimus prolongs recovery from delayed graft function after cadaveric renal transplantation. Amer. J. Transplant., 3 (4), 416-423.

Moore, J., Tan, K., Cockwell, P., Krishnan, H., McPake, D., Ready, A., Mellor, S., Hamsho, A., Ball, S., Lipkin, G., Borrows, R. (2007). Predicting early renal allograft function using clinical variables. Nephrol. Dial. Transplant., 22 (9), 2669-2677.

Quiroga, I., McShane, P., Koo, D. D. H., Gray, D., Friend, P. J., Fuggle, S., Darby, C. (2006). Major effects of delayed graft function and cold ischaemia time on renal allograft survival. Nephrol. Dial Transplant., 21,1689-1696.

Sánchez-Fructuoso, A., Sánchez, D. P., Vidas, M. M., de Novales, E. L., Guzmin, A. B. (2004). Nonheart beating donors. Nephrol. Dial. Transplant., 19, 26-31.

Sola, R., Alarcon, A., Jimenez, C., Osuna, A. (2004). The influence of delayed graft function. Nephrol. Dial. Transplant., 19 (3), 32-37. 
ATLIKTĀ NIERES TRANSPLANTĀTA FUNKCIJA AGRĪNĀ PĒCTRANSPLANTĀCIJAS PERIODĀ UN TĀS IETEKME UZ VĒLINNIEM PĒCTRANSPLANTĀCIJAS REZULTĀTIEM

Atliktā nieres transplantāta funkcija ir samērā bieža komplikācija, kura negatīvi ietekmē agrīno pēctransplantācijas periodu. Dati par tās ietekmi uz vēlīno periodu ir pretrunīgi. Šajā pētījumā aprakstîti piecu gadu novērošanas rezultāti 248 pacientiem, kuriem tika veikta nieru transplantācija no mirušiem donoriem. Visi pacienti tika sadalīti divās grupās: ar atlikto transplantāta funkciju $(\mathrm{n}=53)$ un tūlītējo funkciju ( $\mathrm{n}$ = 195). Tika izpētīti atliktās transplantāta funkcijas iemesli un tās ietekme uz transplantātu un pacientu izdzīvošanu, akūtas atgrūšanas un hroniskās disfunkcijas biežumu. Atliktās transplantāta funkcijas biežums bija 21,4\%, to ietekmēja tādi faktori kā recipienta vecums un svars, donoru vecums un k̦ermeņa masas indekss, asistolijas un hipotensijas epizodes donoriem pirmseksplantācijas periodā $(P<0,05$ visiem), aukstuma išēmijas ilgums $(P>0,05)$. Atliktās transplantāta funkcijas gadījumā bija ievērojami augstāks akūtas atgrūšanas biežums $(P<0,001), 1,5$ un 5 gadu transplantātu izdzīvošana un 1,5 gada pacientu izdzīvošana bija zemāka $(P<0,05$ visiem). Jāsecina, ka atliktā transplantātu funkcija negatīvi ietekmē transplantātu un pacientu izdzīvošanu, sevišḳi pirmo 1,5 gadu laikā pēc transplantācijas. 